\title{
Forum
}

\section{Forest decentralization for REDD? A response to Sandbrook et al.}

SVEN WUNDER

andbrook et al. (2010) discuss critical governance issues $\checkmark$ around implementation of programmes for reducing emissions from deforestation and forest degradation (REDD). They claim that decentralization has had positive impacts on forest conservation and that REDD will probably reverse that process, with recentralization eventually hurting both people and forests. Here I argue that both causal suppositions are too hasty.

Why should decentralization and devolution lead to improved forest conservation? Because the subsidiarity principle would seemingly also apply to forests: placing responsibility at the least centralized competent level will enable local people to make rational forest management decisions. Nevertheless, where forests are abundant, local people often have a rational self-interest in converting them to other uses. Getting more power eases that task. This is why, for example in the Andes, communities frequently seek permission to divide up their forest commons so they can invest in pasture creation or cropping at their lowest competent level: the private household. Widespread tenure insecurity and poor governance in tropical frontier forests may cause forest degradation through quasi open-access but insecurity will also often impede investments in deforestation. When hard conservation-development tradeoffs prevail decentralization may backfire: it may improve livelihoods but conservation impacts are ambiguous at best (Tacconi, 2007).

What about the empirical evidence? As with several previous studies by decentralization advocates Sandbrook et al. draw much on data from the International Forestry Resources and Institutions network. For instance, Chhatre \& Agrawal (2008) scrutinized the prospects for REDD in 80 forest commons in South Asia (56\%), East Africa (28\%) and Latin America (16\%). But this sample does not match well with the location of carbon-dense high deforestation: the expanding agricultural frontiers of Indonesia, Brazil and Central Africa, focus of major REDD efforts, are not represented. Sampling criteria in Ostrom \& Nagendra (2006) are less transparent but seemingly similar biases towards established agricultural areas apply.

Resource-use dynamics in agricultural frontiers with extensive forests, typically poorer infrastructure and governance, and weaker institutions and land tenure are bound to be very different from fragmented forests. Ostrom (1999)

Sven Wunder Center for International Forestry Research, Rua do Russel, 450/601, CEP 22.210-010, Rio de Janeiro, Brazil. E-mail s.wunder@cgiar.org showed that communal self-governance is much more likely to succeed when forests are not too big to monitor, not too rich in resources to tempt rent-seekers, forest production is biophysically predictable, previous organizational experience is consolidated, and users share low timediscount rates and inherent forest values. In how many frontier forests with high deforestation rates are these conditions satisfied? I cannot think of many. Often the legitimate communities to whom power is to be devolved may be hard to identify because multiple land claims are overlapping in space and time. Predicating on REDD from samples dominated by forest fragments runs the risk of barking up the wrong trees: not the ones threatened by large-scale deforestation that could make a major contribution to climate mitigation.

Turning to national decentralization cases, my reading of experiences also differs from that of Sandbrook et al.. The notion that decentralization and devolution go along with more conservation is problematic in countries with high deforestation. Sandbrook et al. cite Mexico and Brazil. Mexico, a global showcase of community forestry and land rights, has high deforestation, and communities are prime receivers of payments for ecosystem services to slow down forest conversion (Muñoz-Piña et al., 2008). For Brazil, the quoted Nepstad et al. (2006) study refers to indigenous areas (which are not fully decentralized) and centrally stateadministrated protected areas both doing well. A new study using matching techniques finds that implementing [protected areas] in zones under high level of current or future anthropogenic threat offers high pay-offs in reducing carbon emissions' (Soares-Filho et al., 2010). In Brazilian agricultural frontiers decentralization has not reduced deforestation. In a comparative study of eight decentralizing Amazon municipalities Toni \& Kaimowitz (2003:374) conclude that 'there is a conflict between (often contradictory) environmental and developmental discourses, and the latter prevails over the former in the decisions of local government' (my translation from Portuguese). Municipal governments are often susceptible to local economic interests in deforestation and thus do not support forest protection efforts. In Indonesia, a prominent absentee on Sandbrook et al.'s list, similar negative decentralization impacts are even stronger, accelerating timber harvesting and oil-palm conversion, driven by local economic rentseeking (Casson \& Obidzinski, 2002).

The second key hypothesis in Sandbrook et al. is that REDD will lead to recentralization, which ultimately 
jeopardizes both local livelihoods and forests. But how likely is this? Insights from the debate on payments for ecosystem services (a relative of REDD) are illustrative. A global review of 287 schemes (Landell-Mills \& Porras, 2002:217) conjectured that such payments may increase power imbalances so that people with weak land rights would increasingly be dispossessed. This widely replicated suspicion links to the so-called Dove hypothesis: high-value resources attract powerful rent-seekers, who will consequently take resource rights away from the poor (Dove, 2003). In practice, however, no Dove hypothesis has applied to payments for ecosystem services: crowding-out has not occurred, probably because per hectare rents are much less than for rich timbers, gold or oil. On the contrary, poor landowners typically consolidate their land-tenure rights by becoming officially recognized providers of payments for ecosystem services. This illustrates that, while precautionary thinking is laudable, fortunately not all the nightmares we can imagine will actually come true.

Correspondingly, one could imagine that REDD will reinforce decentralization and devolution of rights, as states recognize they cannot effectively reduce deforestation by centralization alone. For instance, Brazil will probably use REDD resources both to strengthen central command-andcontrol measures and Amazon land-tenure clarification (the Terra Legal programme), as well as programmes of payments for ecosystem services. Ecuadorian and Peruvian national programmes for such payments could benefit from REDD. Many policy tools are thus available and the political economies in REDD recipient countries are too diverse to predict singular outcomes. Conditionality is the key conceptual safeguard: if inefficient governments waste rents centrally without avoiding deforestation then international REDD transfers must be stopped. Sandbrook et al. believe these payments on proven delivery 'could exclude small-scale bodies who lack the start-up capital needed to achieve REDD'. Yet, many donors are ready to support decentralized REDD pilot projects and 'nested approaches' to REDD are among the most popular. Hence, Sandbrook et al. are correct in pointing to governance reforms as central to REDD's success but their generalized pessimism seems unwarranted.

In summary, decentralization and devolution may have been promising for conservation in some fragmented forest landscapes but in extensive forest-agricultural frontiers, where REDD really matters, they are not. When Sandbrook et al. admit to decentralization's failure to deliver conservation they believe it is because the process was incomplete or erratic. I would rather conclude with Tacconi (2007) that structural obstacles prevail:

... the ideal model of democratic decentralization described in the literature is unlikely to be implemented given the governance constraints in many tropical forest countries. Even if that model could be implemented ... decentralization cannot be expected to necessarily lead to forest conservation.

What does this mean for policy? We can generally view REDD as a principal-agent approach: global carbonmitigation interests (the principal) pay national governments (an intermediary) to use mixes of incentives and disincentives to persuade a subset of local stakeholders (the agent) to deforest less. Nothing should make us expect that maximizing local agents' rights per se would generally be conducive to the principal's environmental objective. On the contrary, stand-alone devolution could be counterproductive. Conversely, and here I agree with Sandbrook et al.'s criticism of the fully centralized model, when the state centralizes decisions and minimizes local people's rights this is also seldom conducive to conservation. However, the middle ground, such as partial devolution (e.g. of land use but not sales rights) or granting environmentally conditional land rights may provide more fertile ground (such as in Brazilian indigenous and extractive reserves). Creative mixtures of incentives and disincentives are needed, and I agree with Sandbrook et al. that institutional and governance reforms constitute essential framework conditions. But while decentralization and devolution can be important complementary conservation tools, I believe making them the centrepiece of REDD would be doomed to fail.

\section{References}

Casson, A. \& Oвidzinsк, K. (2002) From New Order to regional autonomy? Shifting dynamics of illegal logging in Kalimantan. World Development, 30, 2133-2151.

Chhatre, A. \& Agrawal, A. (2008) Forest commons and local enforcement. Proceedings of the National Academy of Sciences of the USA, 105, 13286-13291.

Dove, M. (1993) A revisionist view of tropical deforestation and development. Environmental Conservation, 20, 17-24.

Landell-Mills, N. \& Porras, I.T. (2002) Silver Bullet or Fool's Gold? A Global Review of Markets for Forest Environmental Services and their Impact on the Poor. International Institute for Environment and Development, London, UK.

Muñoz-Piña, C., Guevara, A., Torres, J.M. \& Braña, J. (2008) Paying for the hydrological services of Mexicó's forests: analysis, negotiation and results. Ecological Economics, 65, 725-736.

Nepstad, D., Schwartzman, S., Bamberger, B., Santilli, M., Ray, D., Schlesinger, P. et al. (2006) Inhibition of Amazon deforestation and fire by parks and indigenous lands. Conservation Biology, 20, 65-73.

Ostrom, E. (1999) Self-Governance and Forest Resources. CIFOR Occasional Paper no. 20. CIFOR, Bogor, Indonesia.

Ostrom, E. \& Nagendra, H. (2006) Insights on linking forests, trees, and people from the air, on the ground, and in the laboratory. Proceedings of the National Academy of Sciences of the USA, 103, 19224-19231.

Sandbrook, C., Nelson, F., Adams, W.M. \& Agrawal, A. (2010) Carbon, forests and the REDD paradox. Oryx, 44, 330-334. 
Soares-Filho, B., Moutinho, P., Nepstad, D., Anderson, A., Rodrigues, H., Garcia, R. et al. (2010) Role of Brazilian Amazon protected areas in climate change mitigation. Proceedings of the National Academy of Sciences of the USA, doi 10.1073/ pnas.0913048107
TAcconi, L. (2007) Decentralization, forests, and livelihoods: theory and narrative. Global Environmental Change, 17, 338348.

Toni, F. \& Kaimowitz, D. (eds) (2003) Municípios e gestão florestal na Amazônia. AS Editores, Natal, Brazil.

\title{
Governance and REDD: a reply to Wunder
}

\author{
Arun Agrawal, Fred Nelson, William M. Adams and Chris Sandbrook
}

$\mathrm{W}$ e welcome Wunder's (2010) response to our article (Sandbrook et al., 2010). Both contributions agree that too little attention has been devoted in international negotiations and discussions to the design and governance aspects of effective, efficient and equitable mechanisms for reducing emissions from deforestation and forest degradation (REDD). Such attention is urgently needed and some devolution, in the form of conditional rights to local communities and authorities, is better than centralized governance or complete devolution. Wunder also agrees with us that decentralization policies have been prompted by reactions against near-complete centralized control exercised by governments who have expropriated forests from people. But few governments, if any, have given up control over forests entirely. As Wunder recognizes, decentralization has typically been incomplete, even when its implementation is tested against the letter of adopted laws and policies (Ribot et al., 2006). We do not argue for complete decentralization (as Wunder believes we do) so much as urge caution against the risk that REDD interventions will reverse decentralization.

Wunder questions the extent to which existing studies of decentralization that point to the positive effects of securing local rights over forests, in particular studies produced by the International Forestry Resources and Institutions (IFRI) research programme, are relevant to the extensive agriculture/forest frontier. Here we disagree. The IFRI research programme provides perhaps the only systematically collected social, ecological and institutional data on local forest use and governance from across multiple country contexts. Its findings are essential to any understanding of forest governance. In showing that local institutions can be effective against deforestation even in contexts that are characterized by high population and market pressures for subsistence forest products, IFRI studies point to the potential benefits such institutions can create for improved forest outcomes on the extensive

Arun Agrawal School of Natural Resources and Environment, University of Michigan, Ann Arbor, Michigan, USA

Fred Nelson Maliasili Initiatives Ltd, Arusha, Tanzania

William M. Adams and Chris SANDBrook (Corresponding author) Department of Geography, University of Cambridge, Cambridge, CB2 3EN, UK. E-mail cgsandbrook@gmail.com forest margin where both these pressures are often attenuated. The key point is that attempts to reverse deforestation on the extensive forest frontier need macro-policy reforms but that such reforms can be strengthened if policy makers also attend to micro-level forest governance by creating strong local forest management institutions.

Wunder's suggestion that 'REDD will reinforce decentralization and devolution of rights, as states recognize they cannot effectively reduce deforestation by centralization alone,' is mostly the expression of a hope, and concedes one of our major points. The idea that REDD will reinforce decentralization is contradicted by evidence from many countries. It is no accident that $85 \%$ of forests are under formal government ownership (White \& Martin, 2002). Groups and individuals that comprise governing regimes have only conceded control over forest lands when pushed to do so by internal or external political or fiscal pressures. In eight of Africa's most-forested countries $98 \%$ of all forests are still formally owned by central governments, a situation that is hard to defend on grounds of technical efficiency, conservation or livelihoods (RRI, 2009).There is ample evidence that increasing natural resource values in African countries leads to politically-motivated recentralization over resources at the expense of those wider interests (Nelson \& Agrawal, 2008). Greater efficiency, by itself, is seldom the raison d'etre of government policies: governments seldom go out of business because they are inefficient.

Past experience of payment for ecosystem services projects is inadequate for thinking about how governments will alter existing forest governance strategies and policies. The available evidence is limited and Wunder (2010) does not provide much additional support for the proposition that payment for ecosystem services contributes to decentralization, or at least does not create incentives for recentralization. Importantly, revenues through potential REDD payments are astronomically larger than for existing payment for ecosystem services projects. When anticipated REDD payments exceed the budget of a government forestry department (as is the case, for example, for Indonesia and Guyana), and subsequent tranches depend on delivering improvements, it is highly unlikely that forestry agencies will risk such payments by depending on a multitude of third parties. 